\title{
STEPWISE SELECTION OF DISCRIMINATIVE VARIABLES BY THE USE OF THE TRACE CRITERION
}

1. Procedure declaration. For given matrices $C_{1}$ and $C_{2}$ stored by lower triangles row by row in one-dimensional arrays, procedure dissteptr performs a search for variables for which the trace criterion attains its maximum.

The procedure allows us for obligatory introduction of variables into the discriminative set (denoted by $\mathscr{D}$ ).

Data:

$p-$ number of variables under consideration; $c 1, c 2[1: p \times(p+1) \div 2]$ - lower triangles of the "between" and "within" corrected cross product matrices, stored row by row;

$l 1$ - the largest number of variables to be introduced into $\mathscr{D}$ while selecting upwards;

12 - the smallest number of variables to be retained in $\mathscr{D}$ while selecting downwards; $n r[1: p]$ - array of nos. (places) of the variables under consideration in the primary (original) data set;

ind $[1: p]$ - array indicating the variables which should be obligatorily introduced into $\mathscr{D}$ before starting the selection procedure: ind $[i]=1$ means that the variable no. $i$ should be introduced into $\mathscr{D}$, otherwise ind $[i]$ should be put equal to $\mathbf{0}$;

eps - small number indicating the machine accuracy.

Results:

ind $[1: p]$ - array indicating the variables contained in $\mathscr{D}$ after finishing 
the selection procedure: ind $[i]=1$ means that the $i$-th variable belongs to $\mathscr{D}$, ind $[i]=0$ means that the $i$-th variable does not belong to it.

Other results are obtained by the use of procedure result which is called after each step including a new variable in $\mathscr{D}$ or excluding it from $\mathscr{D}$.

Other parameters:

trace - identifier of the function evaluating the trace of the product of two matrices $A^{\prime}$ and $B^{\prime}$ contained in matrices $A$ and $B$ of larger size, stored by lower triangles row by row. The matrices $A^{\prime}$ and $B^{\prime}$, for which the trace criterion is calculated, are identified by an integer array ind whose elements equal 1 indicate which rows and columns of the larger matrices should be taken. This function should be headed as follows:

real procedure $\operatorname{trace}(p, c 1, c 2$, ind $)$;

value $p$

integer $p$;

array $c 2, c 2$;

integer array ind;

An example of realization of this function is given on page 371 .

onestep - identifier of the procedure described in [2];

result - identifier of the procedure printing intermediate results of the search procedure after a new variable has been introduced in $\mathscr{D}$ or eliminated from $\mathscr{D}$; this procedure was described in [2] under the heading outratio.

\section{Method used.}

2.1. The trace criterion is defined as the product of two matrices $B$ and $W^{-1}$, where $B$ stands for the between-groups cross product matrix, and $W$ for the within-groups or error cross product matrix. Tests of significance between vectors of means of several groups can be formulated on the base of this statistic (see [1] and [4]).

Consider variables labelled $1,2, \ldots, p$, and let $r$ be a given integer. Our aim is to choose such a subset $i_{1}, i_{2}, \ldots, i_{r}$ for which

$$
\operatorname{tr}\left(B_{i_{1} i_{2} \ldots i_{r}} W_{i_{1} i_{2} \ldots i_{r}}^{-1}\right)=\max
$$

where $B_{i_{1} i_{2} \ldots i_{r}}$ and $W_{i_{1} i_{2} \ldots i_{r}}$ are submatrices of $B$ and $W$ determined by the intersection of rows and columns with indices $i_{1}, i_{2}, \ldots, i_{r}$.

2.2. For stepwise inversion of a grammian matrix $W$ the Gauss-Jordan algorithm may be applied. Having this in mind it is easy to programme an algorithm for stepwise selection of discriminative variables by the use of the trace criterion. Applying sequentially the modified Gauss-Jordan 
procedure dissteptr(p,c1,c2,11,12,nr,ind, eps, trace, onestep, result);

value $p, 11,12$, eps;

real eps;

integer $\mathrm{p}, 11,12$;

arreay $c 1, c 2$;

integer array $\mathrm{nr}$, ind;

real procedure trace;

procedure onestep, result;

begin

real $x, z$;

integer $\mathrm{k}, \mathrm{I}, \mathrm{q}, \mathrm{r}, \mathrm{s}$;

array $c 3[1: p \times(p+1)+2]$;

$I:=\mathrm{k}:=0$;

for $q:=1$ step 1 until $p$ de

begin

$\mathrm{k}:=\mathrm{k}+\mathrm{q} ;$

if ind $[q]=1$

then

begin

if $c 1[\mathrm{k}]>\operatorname{eps} \wedge c 2[\mathrm{k}]>\mathrm{eps}$

then

besin

onestep $(q, 1.0, p, c 2)$;

$I:=1+1$;

end $c 1[k]>\operatorname{eps} \wedge \mathrm{c}[\mathrm{k}]>\operatorname{eps}$

else ind $[q]:=0$

end $\operatorname{ind}[q]=1$

end q;

if $1>0$ 
then

begin

$z:=-\operatorname{trace}(p, c 1, c 2$, ind $)$;

result $(p, I, z, n r$, ind $)$

end $1>0$;

if $11>\mathrm{p}$

then $11:=0$;

neztvar:

iff $1 \geq 11$

then go to back;

$z:=.0$;

$k:=r:=0 ;$

for $q:=1$ step 1 until $p$ do

begin

for $s:=p \times(p+1) \div 2$ step -1 unti] 1 de $c 3[s]:=c 2[s]$;

$\mathrm{k}:=\mathrm{k}+\mathrm{q}$;

if ind $[q]=0 \wedge c 3[k]>$ eps

then

begin

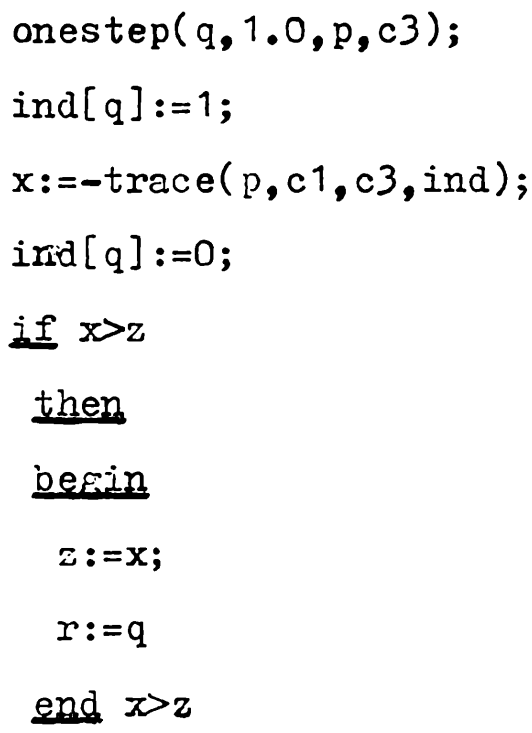


end ind $[\mathrm{q}]=0 \wedge \mathrm{c} 3[\mathrm{k}]>$ eps

end $q$;

if $r>0$

then

begin

$$
\begin{aligned}
& \text { onestep }(r, 1.0, p, c 2) \text {; } \\
& \text { ind }[r]:=1 ; \\
& I:=1+1 ; \\
& \text { result }(p, I, z, n r, \text { ind }) \text {; } \\
& \text { so to nextvar } \\
& \text { end } r>0 ;
\end{aligned}
$$

back:

if $12 \geq 1$

then go to fin;

$\mathrm{z}:=.0$;

$\mathrm{k}:=\mathrm{q}:=0$;

for $r:=1$ step 1 until $p$ de

besin

$\mathrm{k}:=\mathrm{k}+\mathrm{r}$;

if $\operatorname{ind}[r]=1$

then

berin

for $s:=p \times(p+1) \div 2$ step -1 untij 1 d

$$
\text { c3 }[s]:=c 2[s] \text {; }
$$

$\operatorname{onestep}(r,-1.0, p, c 3)$;

$\operatorname{ind}[r]:=0$;

$x:=-\operatorname{trace}(p, c 1, c 3$, ind $)$;

ind $[r]:=1$;

if $x>z$

then 


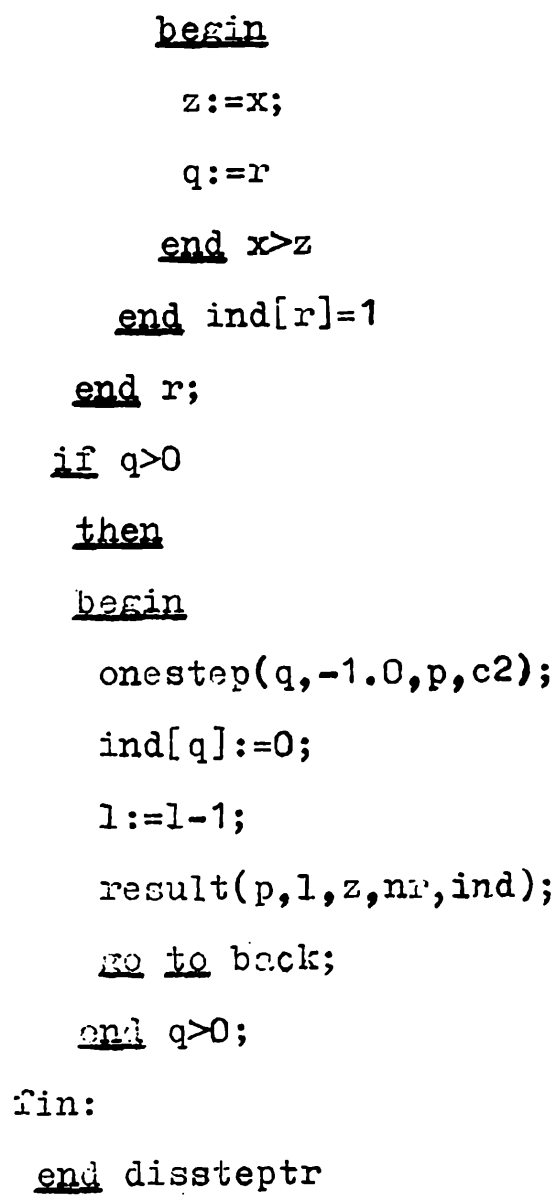

transformations to a given matrix $W$ of size $p \times p$ we obtain finally the inverse of the transformed matrix $W$,

$$
W^{-1}=T_{p} T_{p-1} \ldots T_{1} W
$$

where $T_{p}, T_{p-1}, \ldots, T_{1}$ denote the transformations described by formulae (3) in [2].

The transformations $T_{r}(r=1,2, \ldots, p)$ may be applied for prescribed values of $r$, say $i_{1}, i_{2}, \ldots, i_{r}$. The transformed matrix determined by the intersection of rows and columns with indices $i_{1}, i_{2}, \ldots, i_{r}$ is the inverse of the input matrix $W_{i_{1} i_{2} \ldots i_{r}}$.

Using the forward transformation $T_{r}$ described by formulae (3) in $[2]$, we include the variable no. $r$ into $\mathscr{D}$. Using the back transformation $\tilde{T}_{r}$ described by formulae (4) in [2] for a variable actually being in $\mathscr{D}$, we exclude this variable from $\mathscr{D}$. Whether a given variable belongs to $\mathscr{D}$ is indicated by the auxiliary array ind whose elements equal 1 signify the presence, and elements equal 0 signify the absence of the variable in $\mathscr{D}$. 
real procedure $\operatorname{trace}(p, c 1, c 2$, ind);

yalue $\mathrm{p}$;

integer $\mathrm{p}$;

array c1,c2;

interer array ind;

begin

real $x$;

integer $i, j, k$;

$x:=.0$;

$\mathbf{k}:=0$;

for $i:=1$ step 1 untiz $p$ de

begin

if ind $[i]=1$

then

begin

for $j:=i-1$ step -1 until 1 do

if $\operatorname{ind}[j]=1$

then $x:=x+c 1[k+j] \times c 2[k+j]$;

$x:=x+.5 \times c 1[k+i] \times c 2[k+i]$

end ind $[i]=1$;

$k:=k+i$

end $i$;

trace $:=x+x$

end trace 
2.3. The algorithm we use proceeds in the following steps:

$1^{\circ}$ Perform the Gauss-Jordan transformations on the matrix $C$ for a given set of declared variables (obligatory introduction, if any).

$2^{\circ}$ Calculate the trace criterion for the submatrices of $B$ and for the transformed matrix $W$ identified by the auxiliary array ind.

$3^{\circ}$ If the actual size of $\mathscr{D}$ is greater than or equal to a given number $l 1$, go to $5^{\circ}$; otherwise, go to $4^{\circ}$.

$4^{\circ}$ If the actual size $l$ is less than the wanted size $l 1$, seek additional variables not belonging to $\mathscr{D}$ which give the greatest rise of the trace criterion. Include this variable (if any) into $\mathscr{D}$, after inclusion augment $l$, and pass to point $3^{\circ}$.

$5^{\circ}$ If the actual size of $\mathscr{D}$ is greater than a given number $l 2$, go to point $6^{\circ}$; otherwise, go to point $7^{\circ}$.

$6^{\circ}$ Seek variables for which after elimination from $\mathscr{D}$ the trace criterion remains the greatest. If there is any such variable, remove it from $\mathscr{D}$, diminish the actual size $l$ and go to point $5^{\circ}$; otherwise, pass tc point $7^{\circ}$.

\section{$7^{\circ}$ Finish. End of the selection procedure.}

The modified Gauss-Jordan transformations can be performed by the use of procedure onestep given in [2]. The trace criterion for variables identified by the array ind can be evaluated by the use of procedure trace given in this paper.

After each call of procedure onestep changing the status quo of $\mathscr{D}$, procedure result is called and we obtain information about the actual value of the trace criterion and the nos. of variables actually being in $\mathscr{D}$.

Notice that the Gauss-Jordan transformation $T_{r}$ is executed only in that case where the diagonal element $w_{r r}$ is greater than eps, a given small number. The inequality $w_{r r}<e p s$ means that the variable no. $q$ is linearly dependent on variables which have been included previously into $\mathscr{D}$.

3. Certification. The results of dissteptr were checked in two modes:

$1^{\circ}$ by calculating the value of the trace criterion strictly from the definition, using procedure cholinversion2 [3] for matrix inversion,

$2^{\mathrm{o}}$ by comparison of the chosen variables with the numbers of variables chosen by disstepw [2].

The results almost always were the same (see the remarks in the certification of procedure disstepw in [2]).

4. Test example. Entering dissteptr with the data

$$
p=5
$$




$$
\begin{aligned}
& c 1[1: 15]=[19482.9350 \\
& 23305.2695 \quad 28505.7548 \\
& 23305.2695 \quad 28505.7548 \quad 28505.7548 \\
& \begin{array}{llll}
11584.5455 & 13927.9221 & 13927.9221 & 6899.1039
\end{array} \\
& 9575.0616 \quad 11968.1315 \quad 11968.1315 \quad 5752.4675 \quad 4815.5146] \text {, } \\
& c 2[1: 15]=[258.9286 \\
& 106.3214 \quad 397.0179 \\
& 106.3214 \quad 397.0179 \quad 397.0179 \\
& \begin{array}{llll}
104.0000 & 138.7143 & 138.7143 & 317.7143
\end{array} \\
& \left.\begin{array}{lllll}
-34.3929 & 174.2321 & 174.2321 & 252.7143 & 478.3036
\end{array}\right] \text {, } \\
& l 1=5, \quad l 2=2, \quad \operatorname{nr}[1: 5]=2,3,4,5,6, \\
& \operatorname{ind}[1: 5]=0,1,0,0,0, \quad e p s={ }_{10}-6,
\end{aligned}
$$

\begin{tabular}{|c|c|c|c|c|c|c|}
\hline No. of call & $r$ & $x$ & \multicolumn{4}{|c|}{$\begin{array}{c}\text { Variables in } \\
\mathscr{D}\end{array}$} \\
\hline 1 & 1 & 71.799671 & 3 & & & \\
\hline 2 & 2 & 111.047882 & 2 & 3 & & \\
\hline 3 & 3 & 113.456186 & 2 & 3 & 6 & \\
\hline 4 & 4 & 116.543725 & 2 & 3 & 5 & 6 \\
\hline 5 & 3 & 113.456186 & 2 & 3 & 6 & \\
\hline 6 & 2 & 111.047882 & 2 & 3 & & \\
\hline
\end{tabular}

and using the function trace of this paper, and also procedures onestep and outratio from [2] we get the following results:

$$
\operatorname{ind}[1: 5]=1,1,0,0,0 \text {. }
$$

This means that the variables chosen are labelled by the array $n r$ as variables no. 2 and no. 3 .

We get also additional results by procedure result, which was called 6 times during the run of disstepw $(p=5)$ :

These are the same results as those obtained by procedure disstepw given in [2].

The calculations were done on the Odra 1204 computer.

\section{References}

[1] H. Ahrens and J. Läuter, Mehrdimensionale Varianzanalyse, Akademie-Verlag, Berlin 1974.

[2] A. Bartkowiak, Algorithm 82: Stepwise selection of discriminative variables by the use of the Wilks criterion, this fascicle, p. 351-364. 
[3] R. S. Martin, G. Peters and J. H. Wilkinson, Symmetric decomposition of a positive definite matrix, Numer. Math. 7 (1965), p. 362-383.

[4] S. J. Press, Applied multivariate analysis, New York 1972.

INSTITUTE OF COMPUTER SCIENCE

UNIVERSITY OF WROCEAW

50-384 WROCEAW

Received on 2. 2. 1978

ALGORYTM 83

ANNA BARTKO WIAK (Wroclaw)

\title{
KROKOWY WYBÓR ZMIENNYCH DO ZBIORU DYSKRYMINACJI METODA SLADU MACIERZY
}

\author{
STRESZCZENIE
}

Procedura dissteptr wybiera metodą krokowa zmienne o największej sile dyskryminacji. Siła dyskryminacji zmiennych jest mierzona za pomoca śladu macierzy $B W^{-1}$, gdzie $B$ oznacza macierz poprawionych iloczynów odchyleń grupowych od średniej generalnej, $W$ zaś macierz poprawionych iloczynów odchyleń wewnątrzgrupowych (macierz błędów przy wielozmiennej analizie wariancji z jednym kierunkiem klasyfikacji). Bliższe omówienie tego kryterium znajduje się w [1] i [4].

Krokowe odwracanie macierzy $W$ odbywa się za pomoca zmodyfikowanego algorytmu Gaussa-Jordana w sposób przedstawiony $w$ [2].

Procedura działa $\mathrm{w}$ trzech etapach:

$1^{\circ}$ Obowiązkowe wprowadzenie $l$ zadeklarowanych zmiennych do zbioru dyskryminacji $\mathscr{D}$ (dopuszcza się możliwość $l=0$ ).

$2^{\circ}$ Dobranie metoda krokowa dalszych zmiennych tak, żeby liczebność zbioru $\mathscr{D}$ osiągnęła wielkość $l 1$, gdzie $l 1$ jest daną liczbą.

$3^{\circ}$ Usunięcie ze zbioru $\mathscr{D}$ odpowiedniej liczby zmiennej tak, aby końcowa liczebność tego zbioru wynosiła $l 2$, gdzie $l 2$ jest daną liczbą.

Po każdym kroku oblicza się wielkość śladu macierzy $B W^{-1}$ dla zmiennych znajdujących się aktualnie w zbiorze $\mathscr{D}$. Zmienne te można identyfikować za pomoca tablicy ind, której wartości równe 1 oznaczają przynależność danej zmiennej do zbioru $\mathscr{D}$, a wartości równe 0 - brak przynależności. Do obliczenia śladu macierzy identyfikowanych w opisany sposób służy funkcja rzeczywista trace. Szukamy takich zmiennych, dla których wielkość obliczonego śladu byłaby możliwie duża.

Dane:

$p$ - liczba rozważanych zmiennych (stopień obliczanych macierzy);

$c 1, c 2[1: p \times(p+1) \div 2]$ - tablice zawierające dolne trójkąty macierzy poprawionych iloczynów odchyleń międzygrupowych i wewnątrzgrupowych, zapamiętanych wierszami; 
Wyniki:

$$
\begin{aligned}
\iota 1- & \text { maksymalna liczba zmiennych w zbiorze } \mathscr{D} ; \\
l 2- & \text { minimalna liczba zmiennych w zbiorze } \mathscr{D} ; \\
n r[1: p]- & \text { numery rozważanych zmiennych według ich pierwotnej } \\
& \text { numeracji w zbiorze danych; } \\
\text { ind }[1: p]- & \text { tablica wskazująca na numery zmiennych (według nume- } \\
& \text { racji w macierzach } C_{1} \text { i } C_{2} \text {, które mają być obowiązkowo } \\
& \text { wprowadzone do zbioru } \mathscr{D} \text { przed rozpoczęciem postepowa- } \\
& \text { nia krokowego: ind }[i]=1 \text { oznacza, że zmienna o nume- } \\
& \text { rze } i \text { powinna być obowiązkowo wprowadzona do zbio- } \\
& \text { ru } \mathscr{D} ; \\
\text { eps - } & \text { mała liczba oznaczająca dokładność maszynową. }
\end{aligned}
$$

ind $[1: p]$ - tablica określająca numery zmiennych (według numeracji w macierzach $C_{1}$ i $C_{2}$ ), znajdujących sie w zbiorze $\mathscr{D}$ :

$$
\operatorname{ind}[i]= \begin{cases}1, & \operatorname{gdy} i \in \mathscr{D}, \\ 0, & \operatorname{gdy} i \notin \mathscr{D} .\end{cases}
$$

Poza tym za pomocą procedury result można otrzymać wyniki częściowe, określające po każdym kroku liczbę i numery zmiennych znajdujących się w zbiorze $\mathscr{D}$. 